NVO-746-7

RECENED BY TIC NOV 131972

A PRELIMINARY SEISMICITY STUDY OF THE SOUTHERN NEVADA REGION

FOR THE MONTH OF SEPTEMBER 1972

U. S. DEPARTMENT OF COMMERCE

NATIONAL OCEANIC AND ATMOSPHERIC ADMINISTRATION

EARTH SCIENCES LABORATORIES

NOVEMBER 1972

PREPARED FOR THE U. S. ATOMIC ENERGY COMMISSION NEVADA OPERATIONS OFFICE UNDER CONTRACT AT $(29-2)-746$ 


\section{DISCLAIMER}

This report was prepared as an account of work sponsored by an agency of the United States Government. Neither the United States Government nor any agency Thereof, nor any of their employees, makes any warranty, express or implied, or assumes any legal liability or responsibility for the accuracy, completeness, or usefulness of any information, apparatus, product, or process disclosed, or represents that its use would not infringe privately owned rights. Reference herein to any specific commercial product, process, or service by trade name, trademark, manufacturer, or otherwise does not necessarily constitute or imply its endorsement, recommendation, or favoring by the United States Government or any agency thereof. The views and opinions of authors expressed herein do not necessarily state or reflect those of the United States Government or any agency thereof. 


\section{DISCLAIMER}

Portions of this document may be illegible in electronic image products. Images are produced from the best available original document. 


\section{LEGAL NOTICE}

This report was propared as an account of work sponsored by the United States Government. Neither the United States nor the United States Atomic Energy Commission, nor any of their employees, nor any of their contractors, subcontractors, or their employees, makes any warranty, express or implied, or assumes any legal liability or responsibility for the accuracy, completeness, or usefulness of any information, apparatus, product or process disclosed, or represents that its use would not infringe privately-owned rights.

Available From The

National Technical Informa tion Service

U. S. Department of Commerce Springfield, Virginia 22151 


\section{A PRELIMINARY SEISMICITY STUDY OF THE SOUTHERN NEVADA REGION}

FOR THE MONTH OF SEPTEMBER 1972

KÉNNETH C。BAYER

KENNETH W. KING

U. S. DEPARTMENT OF COMMERCE

NATIONAL OCEANIC AND ATMOSPHERIC ADMINISTRATION

EARTH SCIENCES LABORATORIES

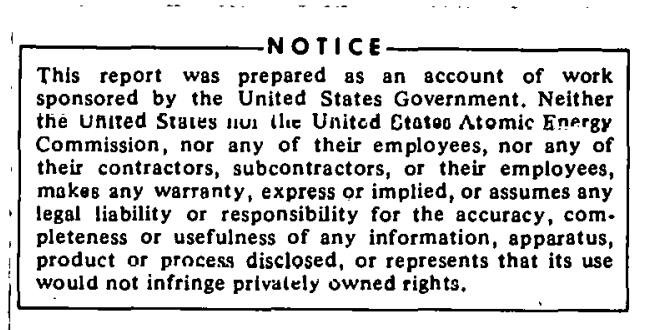

1
1
$\vdots$
$\vdots$

NOVEMBER 1972

PREPARED FOR THE U. S. ATOMIC ENERGY COMMISSION

NEVADA OPERATIONS OFFICE

UNDER CONTRACT AT(29-2)-746

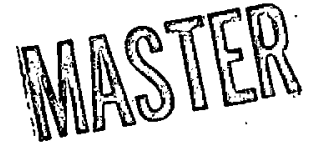


‘

THIS PAGE

\section{WAS INTENTIONALLY \\ LEFT BLANK}


TABLE OF CONTENTS

Page

ABSTRACT

1. ' INTRODUCTION 1

2. DISCUSSION - . 4

3. GENERAL SEISMICITY ? 5

4. ACKNOWLEDGMENTS $\quad 10$

5. REFERENCES 11

APPENDIX A - Hypocenter Summary A-1

APPENDIX B - Atomic Energy Commission (AEC) B-1

Announced Events

TABLE 1 - Seismic Station Constants 3

FIGURES

1. Station Location Map . . . . 2

2. Earthquakes in the Southern Nevada Region for the 6 Month of September 1972

3. Earthquakes on the Nevada Test Site 8 for the Month of September 1972 


\title{
A PRELIMINARY SEISMICITY STUDY OF THE SOUTHERN NEVADA REGION FOR THE MONTH OF SEPTEMBER 1972
}

Kenneth C. Bayer

Kenneth..W. King

\begin{abstract}
A cooperative (ESL, Sandia Laboratories, USGS) network of 21 seismic velocity sensitive stations is operated in the southern Nevada area; the stations are monitored by the NOAA/ESL Nevada Special Projects Party located in Las Vegas; Nevada.

A significant increase in seismic activity on the Nevad a Test Site (NTS) was observed following two nuclear explosions in the Yucca Flat area. Two seismicity maps are included; one of the southern Nevada region and the second of the seismicity on the Nevada Test Site.(NTS).

This is the third in a series of monthly seismic bulletins covering the southern Nevada region, monitored by the Las Vegas, Nevada-based Special Projects Party. The output is listed in the Hypocenter Summary. The listing is the result of data scaled only from the local cooperative network, and solutions determined by a local-epicenter program. A total of 79 epicenters is listed.
\end{abstract}

\section{INTRODUCTION}

This report contains a summary of earthquakes recorded by a network of 19 seis mograph stations in the southern Nevada region, and 2 stations in central Nevada, for the month of September 1972. This is the third in a series of monthly seismicity reports, Bayer (1972), embracing southern Nevada and the border zones of Arizond, California, and Utah.

The southern Nevada seismic network station locations are shown in figure 1. All stations are located in Nevada with the exception of Leeds (LEE) in Utah, and Darwin (DAC) in California. This net is operated by the three cooperating agencies listed in table 1. The data from all of the stations are recorded on $16 \mathrm{~mm}$ film and magnetic tape by the Nevada Special Projects Party (NSPP) of the National Oceanic and Atmospheric 


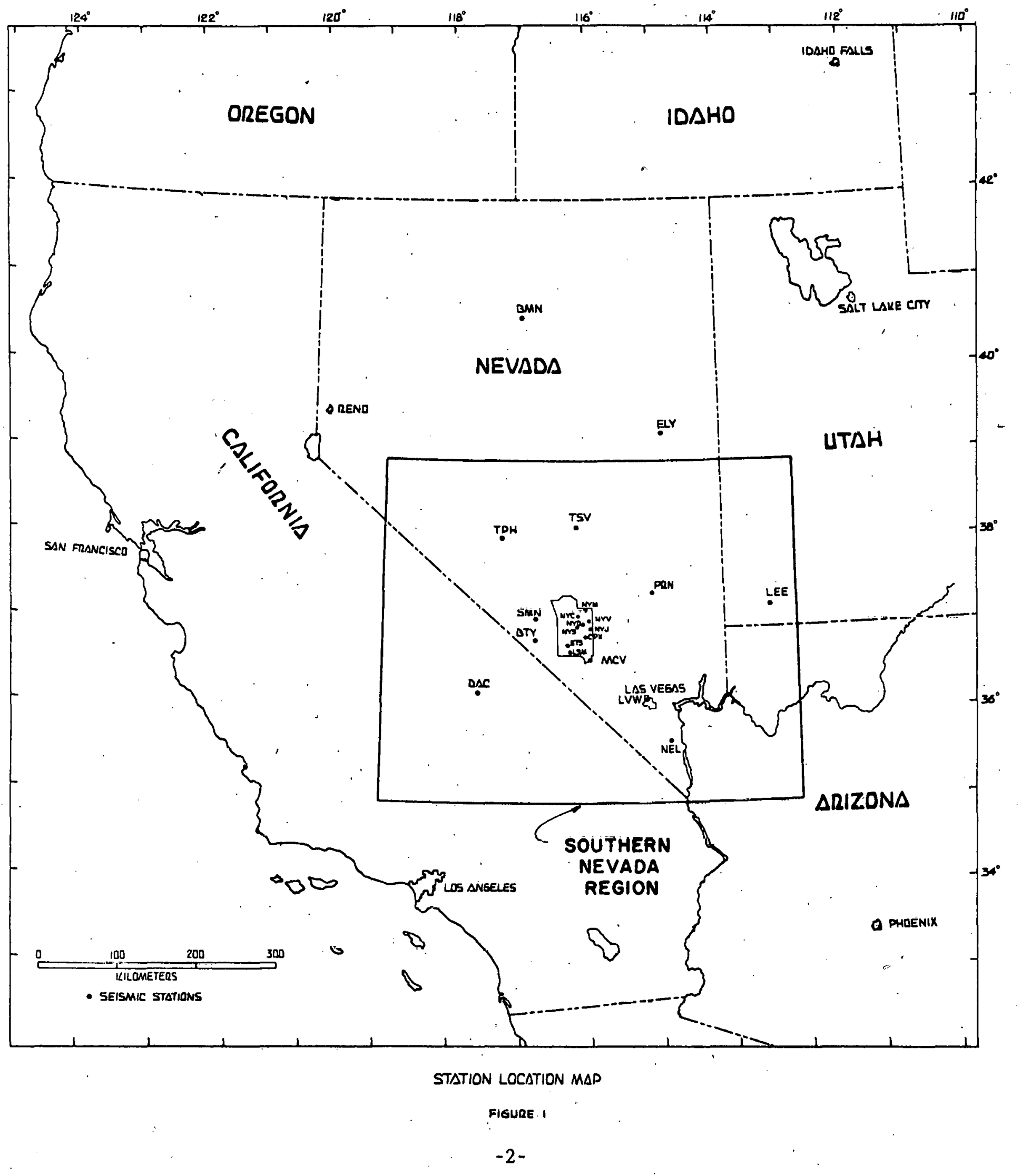


TABLE I

SEISMIC STATION CONSTANTS

\begin{tabular}{ccccccc}
\hline Code & * Station & Latitude & Longitude & Elev. & Inst. & Approx. Magni- \\
(West) & Name & (Neters) & Comp. & fication @ 1 Hz \\
\hline
\end{tabular}

\section{NOAA/ESL/NEVADA SEISMOGRAPH STATIONS}

$\begin{array}{lllllll}\text { BTY } & \text { Beatty } & 36^{\circ} 53.63^{\prime} & 116^{\circ} 45.88^{\prime} & 1008 & \text { SPZ } & 100 \mathrm{~K} \\ \text { CPX } & \text { CP-1 (Control Point \#1) } & 36^{\circ} 55.92^{\prime} & 116^{\circ} 03.33^{\prime} & 1285 & \text { SPZ } & 110 \mathrm{~K} \\ \text { ETS } & \text { Engine Test Stand } & 36^{\circ} 49.95^{\prime} & 116^{\circ} 18.50^{\prime} & 1158 & \text { SPZ } & 0.1 \mathrm{~K} \\ \text { LSM } & \text { Little Skull Mountain } & 36^{\circ} 44.32^{\prime} & 116^{\circ} 16.68^{\prime} & 1146 & \text { SPZ } & 220 \mathrm{~K} \\ \text { LVW } & \text { Las Vegas (West) } & 36^{\circ} 10.20^{\prime} & 115^{\circ} 11.25^{\prime} & 654 & \text { SPZ } & 3.3 \mathrm{~K} \\ \text { MCV } & \text { Mercury } & 36^{\circ} 38.01^{\prime} & 115^{\circ} 59.99^{\prime} & 1158 & \text { SPZ } & 100 \mathrm{~K} \\ \text { PRN } & \text { Pahroc Range } & 37^{\circ} 26.50^{\prime} & 115^{\circ} 04.00^{\prime} & 1524 & \text { SPZ } & 105 \mathrm{~K} \\ \text { SMN } & \text { Sleeping Mountain } & 37^{\circ} 08.60^{\prime} & 116^{\circ} 46.00^{\prime} & 1246 & \text { SPZ } & 25 \mathrm{~K} \\ \text { TSV } & \text { Twin Springs } & 38^{\circ} 12.10^{\prime} & 116^{\circ} 10.50^{\prime} & 1585 & \text { SPZ } & 105 \mathrm{~K}\end{array}$

SANDIA LABORATORIES STATIONS

$\left.\begin{array}{llllll}\text { BMN } & \text { Battle Mountain } & 40^{\circ} 25.90^{\prime} & 117^{\circ} 13.30^{\prime} & .1524 & \text { SPZ } \\ \text { DAC } & \text { Darwin, California } & 36^{\circ} 16.62^{\circ} & 117^{\circ} 35.62^{\prime} & 1432 & \text { SPZ } \\ \text { ELY } & \text { Ely } & 39^{\circ} 07.88^{\prime} & 114^{\circ} 53.52^{\prime} & 2012 & \text { SPZ } \\ \text { LEE } & \text { Leeds, Utah } & 37^{\circ} 14.58^{\circ} & 113^{\circ} 22.60^{\prime} & 1067 & \text { SPZ } \\ \text { NEL } & \text { Nelson } & 35^{\circ} 42.74^{\prime} & 114^{\circ} 50.61^{\prime} & 1052 & \text { SPZ } \\ \text { TPH } & \text { Tonopah } & 38^{\circ} 04^{\prime} .9^{\prime} & 117^{\circ} 13.21^{\prime} & 1890 & \text { SPZ }\end{array}\right\}$ Variable

U. S. GEOLOGICAL SURVEY, YUCCA FLATS NEVADA STATIONS

$\left.\begin{array}{llllll}\text { NYC } & \text { Charley } & 37^{\circ} 09.30^{\prime} & 116^{\circ} 09.32^{\prime} & 1574 & \text { SPZ } \\ \text { NYJ } & \text { Joshua Tree } & 37^{\circ} 00.48^{\prime} & 115^{\circ} 58.48^{\prime} & 1195 & \text { SPZ } \\ \text { NYM } & \text { Climax Mine } & 37^{\circ} 13.88^{\prime} & 116^{\circ} 03.14^{\prime} & 1489 & \text { SPZ } \\ \text { NYR } & \text { Receiver Site } & 37^{\circ} 03.32^{\prime} & 116^{\circ} 05.50^{\prime} & 1188 & \text { SPZ } \\ \text { NYS } & \text { Syncline Ridge } & 37^{\circ} 01.95^{\prime} & 116^{\circ} 10.13^{\prime} & 1402 & \text { SPZ } \\ \text { | NYV } & \text { Vern } & 37^{\circ} 06.77^{\circ} & 115^{\circ} 59.40^{\prime} & 1340 & \text { SPZ }\end{array}\right\}$ (20X Viewer)

* Location in Nevada, unless otherwise specified. 
Administration/Earth Sciences Laboratories (NOAA/ESL), Las Vegas, Nevada. The Hypocenter Summary (appendix A) is the result of programming only data from the Nevada network to compute earthquake locations.

\section{DISCUSSION}

The principal objective of the monthly report is to distribute preliminary seismic data acquired from the Southern Nevada Network of Seismograph Stations. A more comprehensive bi-annual seismicity report similar to Bayer (1972) is planned for publication at a later time.

Recorded arrival times and amplitudes are scaled in Las Vegas. Periodically, the properly formatted data are keypunched at the Las Vegas office and run through a local earthquake program described by Bolt, et al. (1964), using a three-layer model. In order to obtain a hypocenter solution with the local station program, P-phase arrival times from at least three stations and one S-phase arrival time for a given earthquake must be present. This compilation is preliminary and may be subject to later revision on the basis of current research.

The individual station readings, from which the hypocenter summary has been derived, are availablc upon request from the F.SI. Nevada Special Projects Party, 3060 South Highland Drive, Las Vegas, Nevada 89109. The phase times are also sent to the National Earthquake Information Center (NEIC) Boulder, Colorado, on punch cards in the NEIC format. The area monitored by the NSPP (for hypocenter locations), is from 35 to 39 degrees north and 113 to 119 degrces west (see fig. 1). Seismic body wave phases from earthquakes which fall in the regional and teleseismic range are also scaled and mailed to the NEIC. 
In the Hypocenter Summary, a " $D$ " following the depth indicates it is a fixed depth solution obtained by choosing the 5 kilometer depth interval that optimized the travel time residuals and standard error. An " $F$ " following the depth indicates the computer found a convergent solution in seven or less iterations by permitting the depth to miove freely.

\section{GENERAL SEISMICITY}

Earthquakes recorded in the southern Nevada region during the month of September 1972, were more frequent than in the previous month; particularly around Scotty's Junction, Nevada, the north end of Death Valley, California, and on the Nevada Test Site. A total of 79 earthquakes were located by the NSPP. All earthquakes plotted on the seismicity map (fig. 2) occurred within the earth's crust. Maximum hypocentral depth was $30.4 \mathrm{~km}$ at the Mohorovicic discontinuity. A preliminary evaluation of magnitudes suggests the great majority of the located events were microearthquakes $(1.0 \leq M \leq 3.0)$

Southern Nevada. A reas northeast and northwest of Scotty's Junction wer e seismically active during the month. Several earthquakes were located on the west flank of Pahute Mesa and to the northwest toward Stonewall Mountain. However, most of the activity in this region occurred northwest of Scotty's Junction at Slate Ridge and in the Palmetto mountains.

The East Pahranagat Range and West Pahranagat Range (both ranges west of Alamo) experienced scattered seismic activity.

Three small earthquakes occurred in the Pintwater Range approximately $45 \mathrm{~km}$ east of the NTS Yucca Flat area. 


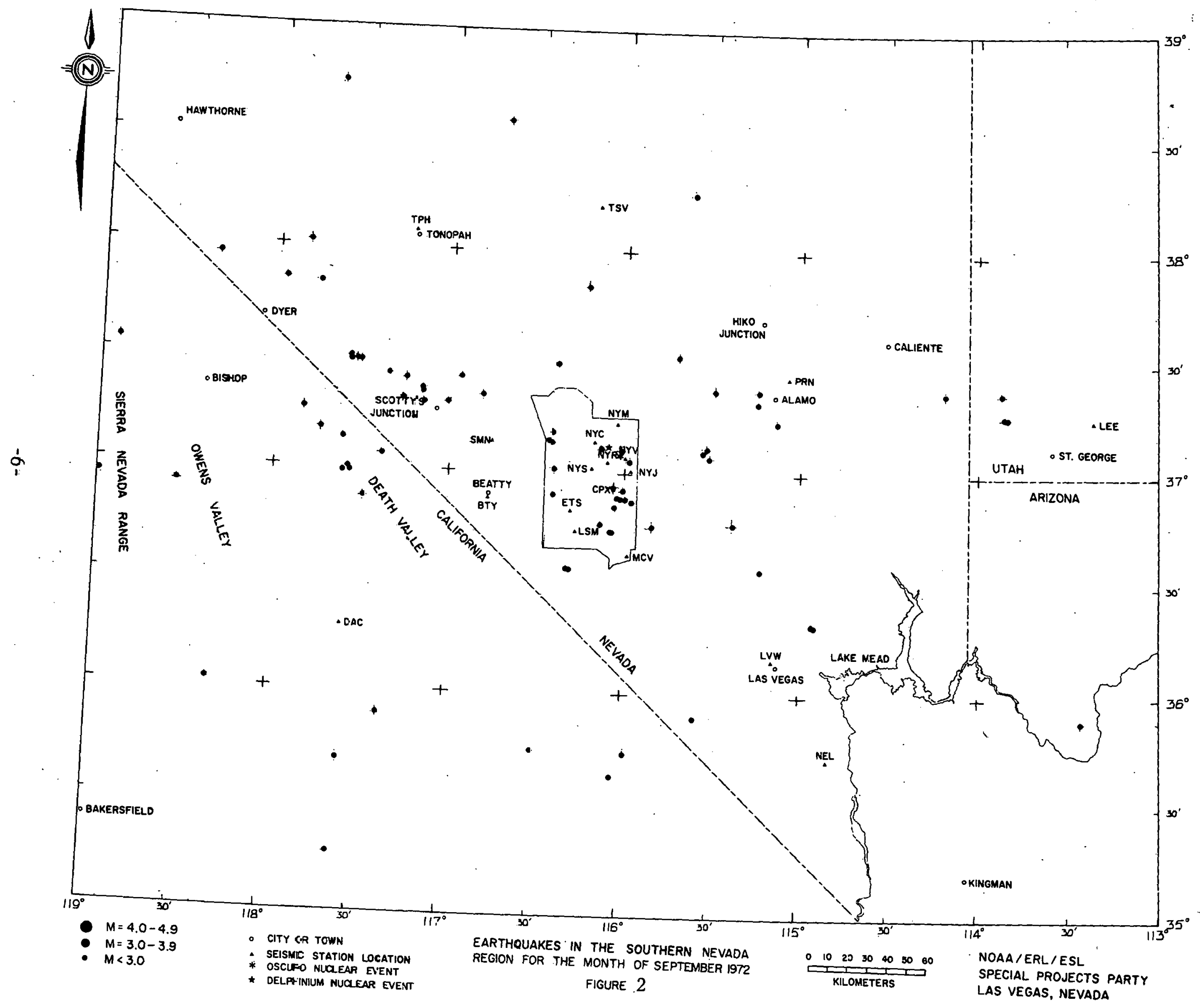


Two earthquakes were located on the south termination of the Arrow Canyon range, approximately $30 \mathrm{~km}$ northeast of Las Vegas.

As indicated on figure 3, the Nevada Test site and adjacent areas continued as the most active sector in the southern Nevada region. There were 18 earthquakes located by the electronic computer on the NTS. Four earthquakes, located on the NTS by the authors, are not included in this bulletin. They are part of a separate report, Navarro, et al. , (October 1972). Only two earthquakes were located on the NTS prior to the Oscuro nuclear event of September 21, 1972. Seismic activity did not increase appreciably until 44 hrs after the Oscuro event. However, immediately following the Delphin- ium nuclear event, there was a significant increase in earthquake activity on the NTS. By the end of the month, activity on the NTS had leveled off, although not terminating. As with the previous month, the most active locale was on the south extension of the Yucca Fault (southeast of Station CPX).

There is no way at present to know whether or not there is a causal link between the two shots and the subsequent flurry of small earthquakes on the NTS. Future events will be monitored, along with the natural seismicity of the region, to investigate the possibility of short-term interaction of the explosions with the local ambient tectonic stresses in the Yucca Flat area.

The remainder of the microearthquakes located in the southern Nevada region exhibit the randomness that is typical of this basin and range area.

Southeast California. The general area between Death Valley and Eureka Valley (Last Chance Range), continued as a seismically active zone. The remainder of this region, particularly Owens Valley, was quite inactive during the month. 


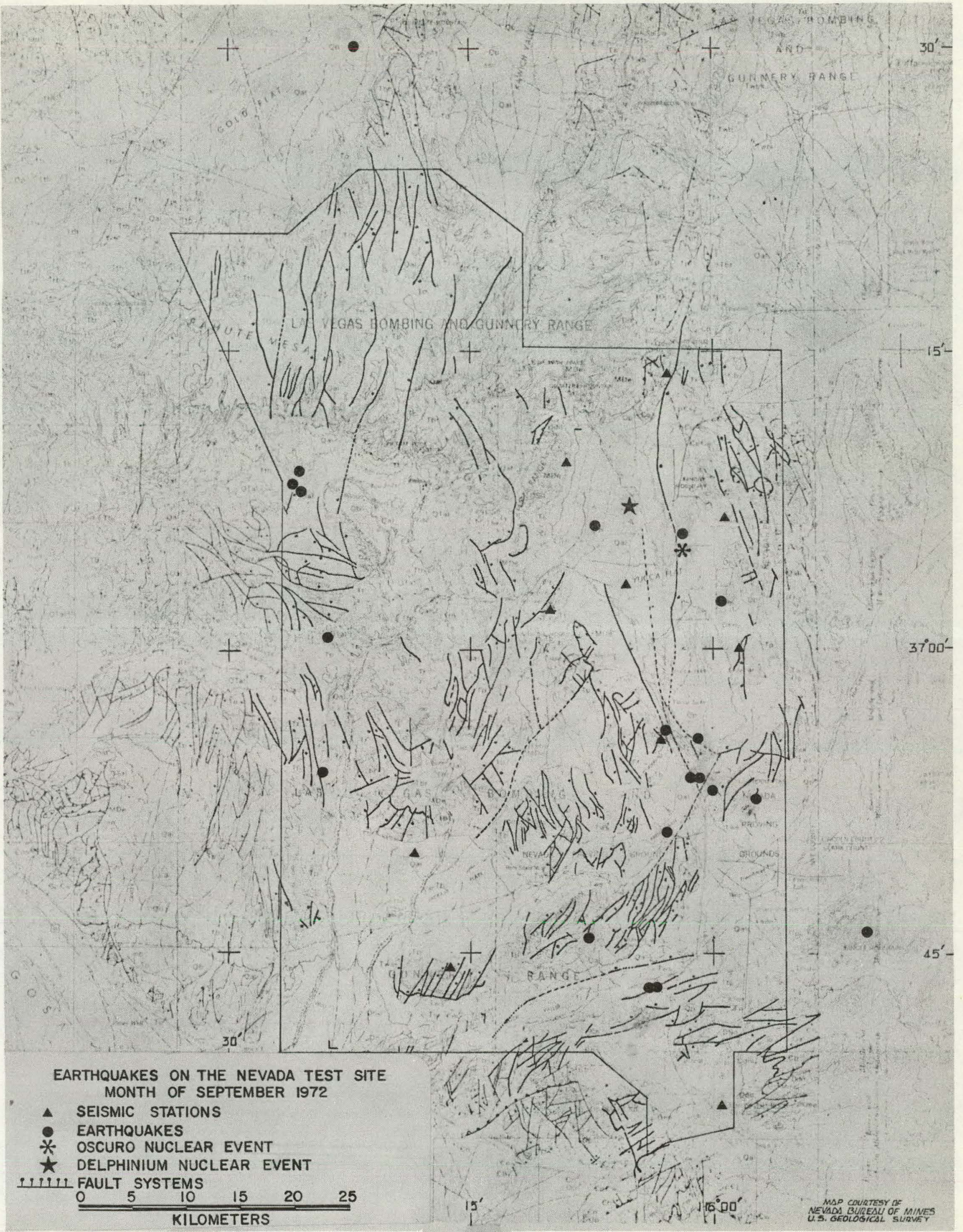

Figure 3 
Southwest Utah. The Bull Valley mountains, northwest of St. George were again active during the month. Three earthquakes occurred within a $7-\mathrm{hr}$ time span and in close proximity to each other.

Northwest Arizona. There was one earthquake located in the vicinity of Blue Mountain on the north rim of the Grand Canyon. This is the first recorded earthquake by the Special Projects Party in this area.

The crustal/upper mantle velocity/depth model is still in the experime ntal stage and will be discussed at a later date.

There were two announced nuclear events conducted by the Atomic Energy Com mission (AEC) on the NTS, during the month, as listed in Appendix B.

\section{ACKNOWLEDGMENTS}

The entire staff of the Nevada Special Projects Party participated in the operation and coordination of the NOAA/ESL seismograph network. Without the cooperation of the Sandia Laboratorles and the U. S. Geological Surveyy, à làrge portion of the data that went into this report would not be available. The authors express grateful acknowledgment to Stanley R. Brockman for the computer processing, and to Thomas W. Bice for data plotting.

The operation of all the seismograph stations and the interpretations of the data from these stations are made possible through the financial support of the Nevada Operations Office of the United States Energy Commission (NVO/AEC), under Contract A $\mathrm{T}(29-2)-746$. 


\section{REFERENCES}

Bay.er, K. C. (1972), Seismicity of the southern Nevada region, December 22, 1971 to July 1, 1972, NVO-746-3, July.

Bayer, K. C. (1972), A preliminary seismicity study of the southern Nevada region for the month of July 1972, NVO-746-4, September.

Bolt, B. A., and T. Turcotte (1964), Computer location of local earthquakes within the Berkeley seismograph network, computers in the mineral industries, Stanford University, 561.

Navarro, R., G. M. Wuollet, and K. C. Bayer (1972), Seismic measurements, event Oscuro, NVO-746-6, Octöber. 
APPENDIX A

HYPOCENTER SUMMARY 
A PPENDIX A

HYPOCENTER SUMMARY

\begin{tabular}{|c|c|c|c|c|c|}
\hline $\begin{array}{l}\text { September } \\
1972 \\
\end{array}$ & $\begin{array}{l}\text { Origin Time } \\
\text { GMT }\end{array}$ & $\begin{array}{c}\text { Latitude } \\
\text { North }\end{array}$ & $\begin{array}{c}\text { Longitude } \\
\text { West }\end{array}$ & $\begin{array}{l}\text { Depth* } \\
(\mathrm{km})\end{array}$ & $\begin{array}{c}\text { Geographic } \\
\text { Area }\end{array}$ \\
\hline 01 & $0005 \quad 17.91$ & $35.74^{\circ}$ & $116.50^{\circ}$ & $10.0 \mathrm{D}$ & Shoshone \\
\hline 01 & 044201.10 & 37.34 & 116.81 & $00.0 \mathrm{D}$ & Thirsty Canyon \\
\hline 01 & $06 \quad 13 \quad 15.63$ & 35.68 & 117.58 & $08.0 \mathrm{~F}$ & Little Lake \\
\hline 02 & 153031.48 & 37.37 & 113.87 & $16.4 \mathrm{~F}$ & St. George \\
\hline 02 & 155033.22 & 37.26 & 113.85 & $06.2 \mathrm{~F}$ & St. George \\
\hline 02 & 224153.95 & 37.26 & 113.83 & $05.0 \mathrm{D}$ & St. George \\
\hline 03 & 210506.75 & 35.74 & 115.97 & $15.0 \mathrm{D}$ & Clark Mtn. \\
\hline 03 & 224955.67 & 36.56 & 116.31 & $00.0 \mathrm{~F}$ & Lathrop Wells \\
\hline 04 & 003112.99 & 35.26 & 117.61 & $00.0 \mathrm{D}$ & Boron \\
\hline 04 & 014011.88 & 36.02 & 118.33 & $00.0 \mathrm{D}$ & Kern Peak \\
\hline 04 & 090448.24 & 36.57 & 116.33 & $11.2 \mathrm{~F}$ & Lathrop Wells \\
\hline 05 & 111606.30 & 37.27 & 117.84 & $10.0 \mathrm{D}$ & Magruder Mtn. \\
\hline 05 & 205559.54 & 37.18 & 117.74 & $11.4 \mathrm{~F}$ & Magruder Mtn. \\
\hline 06 & 96. & 37.37 & 114.19 & $00.0 \mathrm{~F}$ & Tule Desert \\
\hline 06 & 035353.43 & 37.13 & 117.61 & $14.0 \mathrm{~F}$ & Magruder Mtn. \\
\hline 07 & 193156.52 & 37.84 & 116.22 & $00.0 \mathrm{~F}$ & Quartzite Mtn. \\
\hline 07 & 203826.74 & 37.04 & 115.98 & $11.5 \mathrm{~F}$ & Groom Lake \\
\hline 07 & 215855.56 & 37.08 & 115.52 & $10.0 \mathrm{D}$ & Groom Lake \\
\hline 08 & 21 il 35.68 & 38.59 & 116.69 & $00.0 \mathrm{D}$ & Mt. Jefferson \\
\hline 10 & 02.3134 .95 & 36.92 & 116.01 & $00.6 \mathrm{~F}$ & Lathrop Wells \\
\hline 10 & 064237.72 & 36.78 & 115.39 & $100.0 \mathrm{~F}$ & Hayford Peak \\
\hline
\end{tabular}


APPENDIX A.

HYPOCENTER SUMMARY

\begin{tabular}{|c|c|c|c|c|c|}
\hline $\begin{array}{c}\text { September } \\
1972 \\
\end{array}$ & $\begin{array}{l}\text { Origin Time } \\
\text { GMT }\end{array}$ & $\begin{array}{r}\text { Latitude } \\
\text { North }\end{array}$ & $\begin{array}{c}\text { Longitude } \\
\text { West }\end{array}$ & $\begin{array}{c}\begin{array}{c}\text { Depth* } \\
(\mathrm{km})\end{array} \\
\end{array}$ & $\begin{array}{l}\text { Geographic } \\
\text { Area }\end{array}$ \\
\hline 12 & 140330.96 & $37.00^{\circ}$ & $117.58^{\circ}$ & $15.0 \mathrm{D}$ & Magruder Mtn. \\
\hline 12 & $1404 \quad 14.65$ & 36.99 & 117.60 & $15.0 \mathrm{D}$ & Dry Mtn. \\
\hline 12 & 220322.32 & 36.99 & 117.57 & $10.0 \mathrm{D}$ & Dry Mtn. \\
\hline 12 & 225058.70 & 37.35 & 117.21 & $05.0 \mathrm{D}$ & Mt. Jackson \\
\hline 12 & 231901.00 & 37.49 & 116.39 & $00.0 \mathrm{D}$ & Silent Canyon \\
\hline 13 & 164404.15 & 37,32 & 117.27 & $00.0 \mathrm{D}$ & Mt. Jackson \\
\hline 14 & 014042.35 & 37.10 & 115.56 & $31.8 \mathrm{~F}$ & Groom Lake \\
\hline 14 & 045355.69 & 37.11 & 115.54 & $22.8 \mathrm{~F}$ & Groom Lake \\
\hline 14 & 173956.80 . & 37.50 & 117.58 & $00.0 \mathrm{~F}$ & Magruder Mtn. \\
\hline 14 & 184151.90 & 37.35 & 117.17 & $00.0 \mathrm{~F}$ & Mt. Jackson \\
\hline 14 & 232954.71 & 37.49 & 117.58 & $05.0 \mathrm{D}$ & Magruder Mtn. \\
\hline 14 & 235658.36 & 37.31 & 117.01 & $00.0 \mathrm{D}$ & Mt. Jackson \\
\hline 15 & 004535.62 & 37.37 & 117.17 & $05.0 \mathrm{D}$ & Mt. Jackson \\
\hline 15 & 005752.90 & 37.49 & 117.52 & $05.0 \mathrm{D}$ & Magruder Mtn. \\
\hline 15 & 044927.99 & 37.40 & 117.26 & $00.0 \mathrm{D}$ & Mt. Jackson \\
\hline 15 & 045833.23 & 37.49 & $\$ 17.54$ & $00.0 \mathrm{D}$ & Magruder Mtn. \\
\hline 15 & 120954.73 & 37.31 & 115.25 & $00.0 \mathrm{~F}$ & Alamo \\
\hline 1.5 & 135309.53 & 37.43 & .117 .36 & $05.0 \mathrm{D}$ & Mt. Jackson \\
\hline 15 & 141357.99 & 37.23 & 115.14 & $25.0 \mathrm{D}$ & Alamo \\
\hline 15 & $2215 \quad 27.34$ & 36.32 & 114.93 & $17.7 \mathrm{~F}$ & Hoover Dam \\
\hline 15 & 234250.69 & 38.75 & 117.66 & $20.0 \mathrm{D}$ & Paradise Peak \\
\hline
\end{tabular}


A PPENDIX A

HYPOCENTER SUMMARY

\begin{tabular}{|c|c|c|c|c|c|}
\hline $\begin{array}{c}\text { September } \\
1972\end{array}$ & $\begin{array}{l}\text { Origin Time } \\
\text { GMT }\end{array}$ & $\begin{array}{l}\text { Latitude } \\
\text { North }\end{array}$ & $\begin{array}{c}\text { Longitude } \\
\text { West }\end{array}$ & $\begin{array}{l}\text { Depth* }^{*} \\
(\mathrm{~km})\end{array}$ & $\begin{array}{c}\text { Geographic } \\
\text { Area }\end{array}$ \\
\hline 16 & $\begin{array}{lll}07 & 00 & 12.63\end{array}$ & $35.89^{\circ}$ & $113.43^{\circ}$ & $10.0 \mathrm{D}$ & Peach Springs \\
\hline 16 & 174733.57 & 37.52 & 115.70 & $05.0 \mathrm{D}$ & Worthington Peak \\
\hline 17 & $07 \quad 1430.86$ & 37.85 & 117.96 & $00.0 \mathrm{D}$ & Silver Peak \\
\hline 18 & 120538.92 & 37.42 & 116.94 & $00.0 \mathrm{~F}$ & Thirsty Canyon \\
\hline 19 & 195420.35 & 35.90 & 115.59 & $21.0 \mathrm{~F}$ & Clark Mtn. \\
\hline 19 & $2213 \quad 14.24$ & 36.32 & 114.92 & $15.0 \mathrm{D}$ & Hoover Dam \\
\hline 19 & 224638.92 & 35.63 & 116.05 & $00.0 \mathrm{D}$ & Shoshone \\
\hline 20 & 072248.51 & 38.02 & 117.83 & $00.0 \mathrm{D}$ & Pilot Peak \\
\hline 21 & 185948.99 & 37.10 & 116.03 & $20.0 \mathrm{D}$ & Silent Canyon \\
\hline 22 & 084825.86 & 37.84 & 117.76 & $10.0 \mathrm{D}$ & Silver Peak \\
\hline 22 & $1622 \quad 19.78$ & 36.56 & 115.23 & $20.0 \mathrm{D}$ & Hayford Peak \\
\hline 23 & 061448.08 & 36.77 & 115.84 & $10.8 \mathrm{~F}$ & Mercury \\
\hline 23 & 155847.96 & 37.14 & 116.43 & $00.0 \mathrm{D}$ & Silent Canyon \\
\hline 23 & 160038.81 & 37.18 & 116.41 & $05.0 \mathrm{D}$ & Silent Canyon \\
\hline 23 & 190520,93 & 37.16 & 116.42 & $05.0 \mathrm{D}$ & Silent Canyon \\
\hline 24 & 063506.84 & 36.74 & 116.08 & $00.0 \mathrm{~F}$. & Lathrop Wells \\
\hline 24 & 075911.89 & 36.74 & 116.07 & $11.2 \mathrm{~F}$ & Lathrop Wells \\
\hline 25 & $09 \quad 10 \quad 17.81$ & 37.54 & 118.90 & $00.0 \mathrm{D}$ & Glass Mtn. \\
\hline 25 & 111455.61 & 37.95 & 118.35 & $15.0 \mathrm{D}$ & David Mtn. \\
\hline 26 & 020156.44 & 36.85 & 116.06 & $20.0 \mathrm{D}$ & Lathrop Wells \\
\hline 26 & $05 \quad 1034.83$ & 37.06 & 117.39 & $16.1 \mathrm{~F}$ & Mt. Jackson \\
\hline
\end{tabular}


A PPENDIX A

HY POCENTER SUMMARY

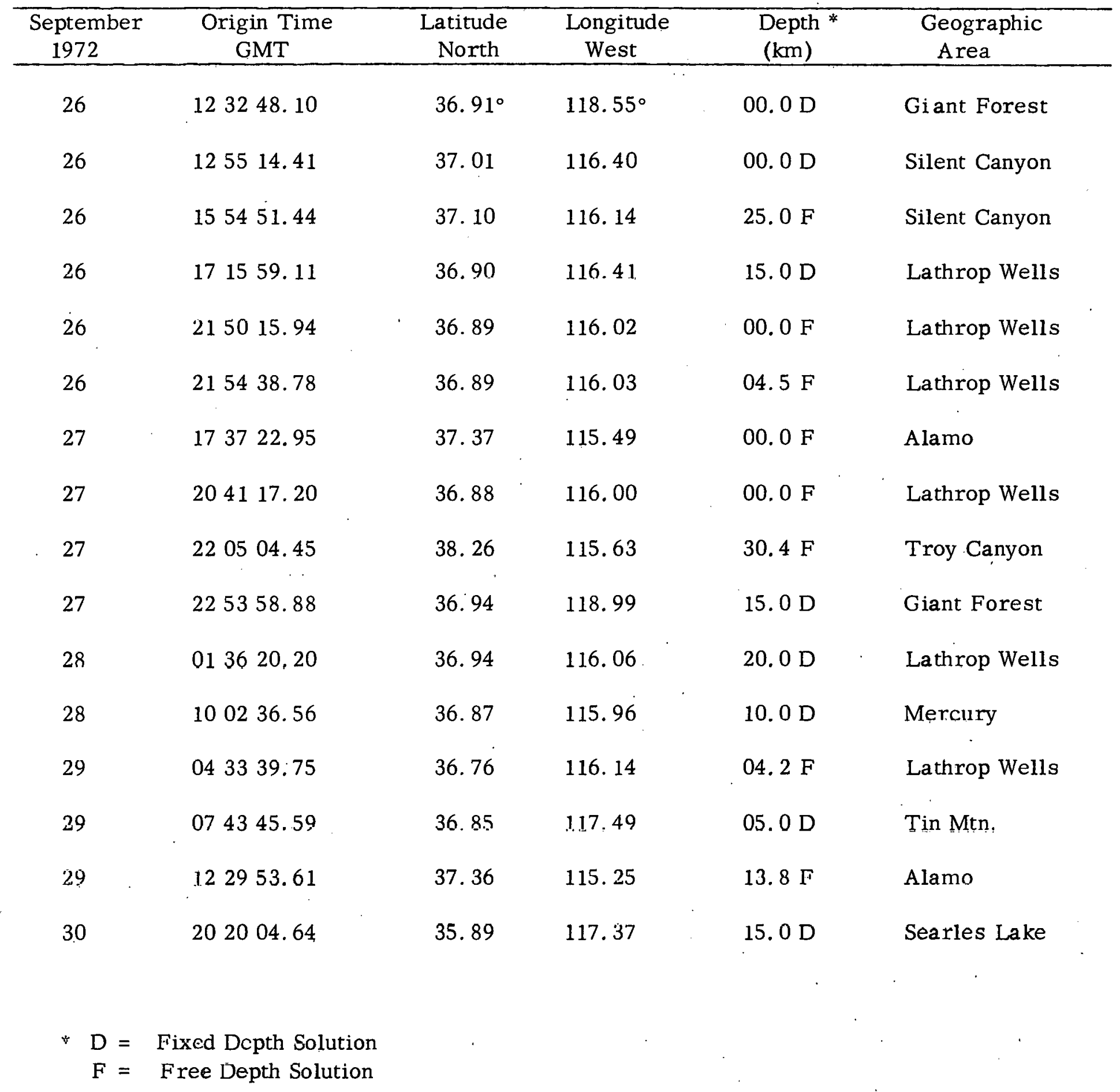


APPENDIX B

ANNOUNCED AEC TESTS 
A PPENDIX B

ANNOUNCED AEC TESTS

(SEPTEMBER 1972)

\begin{tabular}{|c|c|c|c|c|c|c|c|}
\hline Event* & $\begin{array}{l}\text { Date } \\
\mathbf{( 1 9 7 2 \mathbf { j }}\end{array}$ & Type & $\begin{array}{l}\text { Time } \\
\text { (GMT) }\end{array}$ & $\begin{array}{c}\text { Latitude } \\
\text { (North) }\end{array}$ & $\begin{array}{l}\text { Longitude } \\
\text { (West) }\end{array}$ & $\begin{array}{c}\text { Elev. } \\
\text { of Shot } \\
\end{array}$ & Magnitude ** \\
\hline & & & $\mathrm{m} \mathrm{s}$ & & & $\overline{\text { (meters) }}$ & $\left(\mathrm{M}_{\mathrm{L}}\right)$ \\
\hline Oscuro & Sept 21 & Nuclear & 153000.186 & $37^{\circ} 04^{\prime} 55.4122^{\prime \prime}$ & $116^{\circ} 02^{\prime} 11.6363^{\prime \prime}$ & 691.7679 & 5.2 \\
\hline Delphinium & Sept 25 & Nuclear & 143000.1593 & $37^{\circ} 07^{\prime} 16.9359^{\prime \prime}$ & $116^{\circ} 05^{\prime} 08.6353^{\prime \prime}$ & 1007.6688 & 4.4 \\
\hline
\end{tabular}

Main Collapse for Oscura at $\sim 1812$ on September $2 i, 1972$

Main Collapse for Delphinium at $\sim 1526$ on September 26,1972 .

* See figure 4 for location

** $\mathrm{M}_{\mathrm{L}}=\mathrm{NSPP}$, Wood-Anderson, Magnitude (Instrument located at Mercury, Nevada) 
Distribution:

Nevada Operations Office, U. S. Atomic Energy Commission, Las Vegas, Nevada

DiBona, B. G.

Douthett, E. M.

Halstead, P. No

Kinnaman, R. L.

Loux, R. R.

Technical Library (3)

\section{NVOO Panel of Consultants}

Bustad, L. K., University of California, Davis, California 95616

Deere, D. U., 2552 S. W. 14th Dr., Gainsville, Florida 36201

Jacobsen, L. S。, 267 Belgreen Place, Oakmont, Santa Rosa, California 95405

Kisslinger, C. , University of Colorado, Boulder, Colorado 80302

Lintz, J., University of Nevada, Reno, Nevada 89507

Newmark, N. M., University of Illinois, Urbana, Illinois 61801

Schultz, V., Washington State University, Pullman, Washington 99163

Thompson, T. F., 713 Crossway Road, Burlingame, California 94010

Van Dorn, W. G. , Scripps Institute of Oceanogra phy, La Jolla, California 92037

Von Lossberg, L. G., Sheppard T. Powell \& Associates, Baltimore, Maryland 21201

Wilson, J. T., University of Michigan, Ann Arbor, Michigan 48105

Wilson, S. D., Shannon \& Wilson, Inc., 1105 N. 38th St., Seattle, Washington 98103

Witherspoon, T. A., University of California, Berkeley, California 91109

National Oceanic \& Atmospheric Administration, ERL/ESL

Algermissen, S. T., Boulder, Colorado 80302

Alldredge, L: R., Boulder, Colorado 80302

Jordan, J. N., Boulder, Colorado 80302

I.ander, J, F., NEIC, Roulder, Colorado 80302

Matthiesen, R. B., San Francisco, California 94105

Mickey, W. V., Boulder, Colorado 80302

Murphy, L。 M。, Boulder, Colorado 80302

Tocher, D. , San Francisco, California 94105 (2)

Von Hake, C., EDS D/62/S, 1135 Broadway, Colorado 80302 
Distribution (cont ${ }^{\prime} d$ )

Advanced Research Projects Agency, Arlingt on, Virginia 20301

Lukasik, S. J.

AFTAC/VELA Seismological Center, Alexandria, Virginia 22314

Pilotte, F. F.

Air Force Office, Scientific Research, Arlington, Virginia 22209

Best, W. J.

Blume, John A. and Associates Engineers, San Francisco, California 94105

Blume, John A. and Associates Research Division, Las Vegas, Nevada 89109

California Institute of Technology, Pasadena, California 91109

Allen, C. R.

Anderson, D.

Nordquist, J.

CER, Geonuclear Corporation, Las Vegas, Nevada 89114

Alcock, E. D.

Colorado School of Mines, Golden, Colorado 80401

Major, M. W。

Romig, $P$.

Simon, Kuth B.

Cornell University, Ithaca, New York 14850

Oliver, J.

Defense Nuclear Agency, Test Command, Kirtland AFB, Albuquerque, New Mexico 87117

Grote B,

Environmental Research Corporation, Las Vegas, Nevada 89102

Hays, W. W。(2) 
Distribution (cont'd)

Lamont Doherty Geological Observatory, Palisades, New York 10964

Sykes, L.

Lawrence-Livermore Laboratory, Livermore, California 94551

Carothers, P. C.

Coyle, P. E.

Germain, L. S.

Hadley, J. W.

Rodean, H. C.

Technical Information Library

Los Alamos Scientific Laboratory, Los Alamos, New Mexico 87544

Ogle, W. E. (3)

Massachusetts Institute of Technology, Cambridge, Massachusetts 02139

A ki, K.

Toksoz, M. N.

Medearis, Kenneth \& Associates, Ft. Collins, Colorado 80521

Medearis, $\mathrm{K}$.

Sandia Laboratories, Albuquerque, New Mexico 87115

Banister, J. R.

Ellett, D. M.

Merritt., M. L.

Sandia Technical Libraries (2)

Tendill, D. M.

Weart, W. E.

St. Louis University, St. Louis, Missouri 63103

Stauder, W. J.

Technical Information Center, U. S. Atomic Energy Commission, Oak Ridge, Tennessee 37830 (2) 
Distribution (cont'd)

University of California, Berkeley, California 91109

Bolt, B.

Cloud, W. K.

University of Nevada, Reno, Nevada 89507

Ryall, A。

University of Utah, Salt I.ake City, Utah 84112

Cook, K. L.

University of Wisconsin, Milwaukee, Wisconsin 53201

Willis, D. C.

U. S. Atomic Energy Commission, Washington, D. C. 20545

Biles, M. B. (DOS)

Camm, Major Gen. Frank A., Hq. (DMA) (3)

Hamburger, R. (DAT)

U. S. Geulugical Survey, Menlu Park, Califurnid 94025

Healy, J. (2) 